\title{
IAMJ
}

INTERNATIONAL

AYURVEDIC

MEDICAL JOURNAL

\section{A REVIEW: A CONCEPT OF AUTOPHAGY WITH SPECIAL REFERENCE TO PAACHANA THERAPY}

\author{
Vaidya Anita Choudhary ${ }^{1}$, Nikita Sharma ${ }^{2}$, Nisha Aggarwal ${ }^{3}$, Sadaf Khan ${ }^{4}$ \\ ${ }^{1} \mathrm{MD}$ Scholar, ${ }^{2} \mathrm{PhD}$ Scholar, ${ }^{3} \mathrm{MD}$ Scholar, ${ }^{4} \mathrm{MD}$ Scholar \\ (PG Department of Samhita and Siddhanta), All India Institute of Ayurveda, New Delhi, India
}

Corresponding Author: anitamundhan@gmail.com

\section{https://doi.org/10.46607/iamj3309092021}

(Published Online: September 2021)

Open Access

(C) International Ayurvedic Medical Journal, India 2021

Article Received: 21/08//2021 - Peer Reviewed: 02/09/2021 - Accepted for Publication: 08/09/2021

Check for updates

\begin{abstract}
Nowadays, our sedentary lifestyle is causing many metabolic diseases, and everyone is trying to understand the importance of Langhana (fasting) therapy today for its prevention. In another way, not only India but also western countries recognize the importance of fasting in different ways. Ayurveda has already been mentioned in a detailed description and its advantages comprehensively. Autophagy is a normal physiological process in the body that deals with the destruction of cells by maintaining homeostasis or normal functioning by protein or Fat degradation. Similarly, Langhana (10 subtypes of fasting) therapy includes the digestion of metabolic toxins, removes the blockage of the channels, thereby aids in minimizing the diseases. This article it's been focused on the concept of Autophagy and its correlation with Pachana therapy which is a subtype of Langhana therapy in Ayurveda.
\end{abstract}

Keywords: Langhana, Pachana, Autophagy.

\section{INTRODUCTION}

A word Autophagy came first in 1960, Autophagy is the natural, regulated mechanism of the cell that removes unnecessary or dysfunctional components. ${ }^{1}$ It allows the orderly degradation and recycling of cellular components. ${ }^{2,3}$ In 2016 Professor Yoshinori Oshumi won Nobel Prize in Physiology or Medicine for the discovery of the mechanism for autophagy under the title of "A fundamental process of degrading and recycling cellular components". ${ }^{4}$ Ayurveda knows the importance of Langhana therapy in which all the metabolic toxins get removed from the body with the removal of all blockage channels. Langhans therapies mean that is the whole procedure of producing lightness in the 
body at various levels like Dosha, Dhatu, Mala or even at Manas i.e. at a psychological level. 10 types of Langhana are described by Acharya Charaka in Sutrasthana ${ }^{5}$, one among them is Pachana or it can be understood as Shamana rupi langhana. It is the treatment principle that is adopted for the digestion of Ama Sansrishtha conditions at various entities i.e. Koshtha, Dosha, Dhatu etc.

\section{Aim and Objectives:}

1. To study the Pachana therapy (one amongst subtype of Langhana) and its correlation of Autophagy

\section{Materials and Methods:}

2. Ayurveda texts like Bruhattryi and the latest different articles on Langhana and Autophagy.

\section{Concept of Langhana:}

\section{Definition}

The procedure which can bring lightness to the body is called Langhana therapy. ${ }^{6}$ Langhana Karma digests Amadosha and increase digestive power and establishes Dosha saamyata. Langhana has been described under a broad aspect, and ten treatment modalities have been grouped under this umbrella.

Definition: The procedure which does Amapachana but does not do Agni Deepana is called Paachana. ${ }^{7}$ In Samadosha conditions, the administration of Pachana Dravyas body becomes light. Pachana has been indicated in the following Madhyabala Rogas like Kapha-Pitta Samuthita Roga, Vami (vomiting), Aatisara (diarrhoea), Hrudroga (heart disease), Visuchika (cholera), Alasaka (meteorism), Jvara (fever), Vibandha (constipation), Gaurav (heaviness), Udgara (belching), Hrlaasa (nausea), Arochaka (appetite loss). ${ }^{8}$

Principle of Langhana: We can understand Langhana with a simple example i.e. Intensity of fire is decreased by the more ash particles remaining on it, Same way in the human body, the digestive fire hampers when the production of Ama (metabolic poisons) is more, which is the main cause of all illnesses. In Langhana therapy Agni (Digestive power) starts digesting Ama Dosha and also clear all blockage of the channels of the body. In this way, it helps to fight against illness 9 . Similarly, in Paachana karma which is one amongst the type of Dashavidha Langhana also doing Ama Paachana (digestion of free radicals) in the body. So, the mode of action of all Langhana types can also be understood with the help of Autophagy.

\section{Concept of Autophagy}

Definition: - Autophagy word derived from the Greek word "auto" means "self and "phage in" means to eat. Autophagy is a normal physiological process in the body that deals with the destruction of cells within the body. It maintains homeostasis or normal functioning by protein or Fat degradation. Autophagy mainly maintains a balance between the manufacture of cellular components and the breakdown of damaged or unnecessary organelles and other cellular constituents. Autophagy also removes and clears damaged cell organelles. It is the natural, regulated mechanism of the cell that disassembles unnecessary or dysfunctional components. In and all it allows the orderly degradation and recycling of cellular components. ${ }^{10}$

\section{Mechanism}

In mammalian cells, All the unwanted and defective cell components are covered by a membrane that is called phagophore, which closes around cytoplasmic material to form a spherical, doublemembraned autophagosome Then the autophagosome outer membrane fuses with a lysosome to form an autolysosome, resulting in degradation of the inner autophagosome membrane and sequestered cargo. And this process increases when cells are starved or when cells are highly exposed to the accumulation of waste material. ${ }^{11}$

Procedure: There are three primary types of autophagy: microautophagy, macroautophagy and a mechanistically unrelated process, chaperonemediated autophagy that only occurs in mammalian cells.

1. Macroautophagy - it is the main pathway, used primarily to eradicate damaged cell organelles or unused proteins. ${ }^{12}$ First the phagophore engulfs the material that needs to be degraded, which forms a double membrane known as an autophagosome, around the organelle marked for destruction. ${ }^{13,14}$ The autophagosome then travels through the cytoplasm of the cell to a lysosome, and the two organelles fuse. Within the lysosome, the contents of the autophagosome are degraded via acidic lysosomal hydrolase. 
2) Micro autophagy- It involves the direct engulfment of cytoplasmic material into the lysosome. ${ }^{15}$

\section{3) Chaperone-mediated autophagy (CMA)- It is a} very complex and specific pathway, which involves the recognition by the hsc70-containing complex. ${ }^{16}$ This means that a protein must contain the recognition site for this hsc70 complex which will allow it to bind to this chaperone, forming the CMAsubstrate/chaperone complex. ${ }^{17}$ This complex then moves to the lysosomal membrane-bound protein that will recognise and bind with the CMA receptor. CMA is significantly different from other types of autophagy because it translocates protein material in a one-by-one manner, and it is extremely selective about what material crosses the lysosomal barrier.

\section{Autophagy and Paachana modality}

Langhans therapy includes the digestion of metabolic toxins, removes the blockage of the channels, and thereby aids in minimizing the diseases. Similarly, Autophagy is to "self-eat", which, by definition, is the process by which the human body consumes its damaged cells and unused proteins. Paachana is one of the procedures for ten types of langhana. All the procedures included in Dhashavidh Langhana are known to cause autophagy. Where autophagy means eating own cells which could convert into harmful substances for the body. So autophagy protects from diseases like cancer, obesity diabetes and all metabolic disorder. Paachana procedure is defined by Sharangdhara Acharya as drugs that catabolized the undigested food, Ama but do not kindle the digestive fire are known as Paachana. Paachana procedure promotes the destruction of unwanted and harmful substances like Ama. Paachana karma is mainly seen in Tikta Rasa Dravya and Tikta Rasa is made up of Akasha and Vayu Mahabhuta. According to Acharya Charaka properties of Tikta Rasa is Upashoshana $^{18}$ i.e. drying and help in the depletion of moisture fat, muscles fat, bone marrow, lymph, pus, sweat, urine, stool, Pitta and Kapha. This Rasa also produces roughness in Strotasa i.e. circulatory channel. Whereas autophagy is also known as a way of cleaning out damaged cells of the body to regenerate newer. The substance that is light, cold, no unctuous, rough, non-slimy, subtle, and abounding, in the qualities of touch are dominated by Vayu. They promote roughness, aversion, movement, non- sliminess, and lightness. Substances that are soft, light, subtle, and smooth and dominated by the qualities of sound are dominated by Akasha. They promote softness, porosity, and lightness. Acharya Ksharpani stated that the substance catabolized Dosha. Whereas Arunadatta stated that the drugs which give strength to Agni and promote digestion of food and Doshas are known as Paachana. ${ }^{19}$ So as Paachana prevents many Santarpanjanya Vyadhi, metabolic disorders. consequently, Paachana Dravya which mainly of Tikta Rasa dominant and Vayu and Akasha Mahabhuta dominant are causes lightness, roughness in circulatory channels etc. also promote catabolism in the body and all those signs have been seen in person when autophagy is happening in their body. As Paachana is one of the procedures of Langhana and other procedures which also include in it i.e. Upavasa (fasting) and Vyayama (exercise) is already proven for causing autophagy ${ }^{20}$. Therefore, from the above concept of the mechanism of Paachana Dravya. It is to be said that Paachana could cause autophagy.

\section{CONCLUSION}

This mechanism of autophagy can be understood more likely be the same as what Paachana Karma performs in our body. Thus, Autophagy may be correlated with Paachana Karma. Broad term Langhana and Autophagy doing Ama Paachana of the body it helps to remove of toxins of the body, fight against infections. Langhana and Autophagy are clearing all channels of the body and recycles damaged organelles. This eliminates intracellular pathogens and thus helps the immune system.

\section{REFERENCES}

1. Klionsky DJ (August 2008). "Autophagy revisited: a conversation with Christian de Duve". Autophagy. 4 (6): 740-3. doi:10.4161/auto.6398. PMID 18567941.

2. Mizushima N, Komatsu M (November 2011). "Autophagy: renovation of cells and tissues". Cell. 147 (4): 728-41. doi:10.1016/j.cell.2011.10.026. PMID 22078875.

3. Kobayashi S (2015). "Choose Delicately and Reuse Adequately: The Newly Revealed Process of 
Autophagy". Biological \& Pharmaceutical Bulletin. 38 (8): 1098-103. doi:10.1248/bpb.b15-00096. PMID 26235572.

4. "The Nobel Prize in Physiology or Medicine 2016". The Nobel Foundation. 3 October 2016. Retrieved 3 October 2016.

5. Charaka Samhita of Agnivesha elaborated by Charaka and Dridhabala, Charaka Samhita with Ayurveda Dipika Commentary by Chakrapanidatta, edited by Yadav Ji Trikamji Acharya, reprinted 2014, New Delhi, Chaukhamba Publications, Sutrasthana, 22 ${ }^{\text {nd }}$ Adhyaya, $18^{\text {th }}$ verse, page no. 121

6. Charaka Samhita of Agnivesha elaborated by Charaka and Dridhabala, Charaka Samhita with Ayurveda Dipika Commentary by Chakrapanidatta, edited by Yadav Ji Trikamji Acharya, reprinted 2014, New Delhi, Chaukhamba Publications, Sutra sthana, 22 ${ }^{\text {nd }}$ Adhyaya, $9^{\text {th }}$ verse, page no. 121

7. Pandit Sarngadharacarya, Sarangadhara Samhita with the commentary Adhamalla's Deepika and Kasirama's Gudhartha-Dipika, edited by Pandit Parasurama Sastri, Vidyasagar, Chaukhambha Orientalia, Varanasi, 2008:35.

8. Charaka Samhita of Agnivesha elaborated by Charaka and Dridhabala, Charaka Samhita with Ayurveda Dipika Commentary by Chakrapanidatta, edited by Yadav Ji Trikamji Acharya, reprinted 2014, New Delhi, Chaukhamba Publications, Sutra sthana, $22^{\text {nd }}$ Adhyaya, $20^{\text {th }}$ verse, page no. 121

9. Ashtanga Hridya of Acharya Vagbhata with the commentaries of Sarvangasundara of Arundatta and Ayurvedarasayana of Hemadri, edited by Pt Hari Sadashiva Shastri, reprinted 2018, New Delhi, Chaukhamba Publications, Nidana Sthan, 22 $2^{\text {nd }}$ Adhyaya, $1^{\text {st }}$ verse, page no.513

10. https://www.news-medical.net.

11. https://www.researchgate.net/publication/31668932 9_Yoshinori_Ohsumi's_Nobel_Prize_for_mechanis ms_of_autophagy_From_basic_yeast_biology_to_t herapeutic_potential

12. Levine B, Mizushima N, Virgin HW (January 2011). "Autophagy in immunity and inflammation". $\begin{array}{llll}\text { Nature. } & 469 & \text { (7330): }\end{array}$ Bibcode:2011Natur.469..323L. doi:10.1038/nature09782. PMC 3131688. PMID 21248839.

13. Mizushima N, Ohsumi Y, Yoshimori T (December 2002). "Autophagosome formation in mammalian cells". Cell Structure and Function. 27 (6): 421-9. doi:10.1247/csf.27.421. PMID 12576635

14. Česen MH, Pegan K, Spes A, Turk B (July 2012). "Lysosomal pathways to cell death and their therapeutic applications". Experimental Cell Research. 318(11): 124551.doi:10.1016/j.yexcr.2012.03.005.

15. Castro-Obregon S (2010). "The Discovery of Lysosomes and Autophagy". Nature Education. 3 (9): 49.

16. Bandyopadhyay U, Kaushik S, Varticovski L, Cuervo AM (September 2008). "The chaperonemediated autophagy receptor organizes in dynamic protein complexes at the lysosomal membrane". Molecular and Cellular Biology. 28 (18): 5747 63. doi:10.1128/MCB.02070-07.PMC 2546938. PMID 18644871.

17. Homma, K.S. (2011). "List of autophagy-related proteins and 3D structures". Autophagy Database. 290. Archived from the original on 2012-08-01. Retrieved 2012-10-08

18. Charaka Samhita of Agnivesha elaborated by Charaka and Dridhabala, Charaka Samhita with Ayurveda Dipika Commentary by Chakrapanidatta, edited by Yadav Ji Trikamji Acharya, reprinted 2014, New Delhi, Chaukhamba Publications, Sutrasthana, 26 ${ }^{\text {th }}$ Adhyaya, 43rd verse, page no. 145

19. Ashtang Hridya of Acharya Vagbhata with the commentaries of Sarvangasundara of Arundatta and Ayurvedarasayana of Hemadri, edited by $\mathrm{Pt}$ Hari Sadashiva Shastri, reprinted 2018, New Delhi, Chaukhamba Publications, Sutra Sthan, 14 Adhyaya, $6^{\text {th }}$ verse, page no. 223

20. Wu NN, Tian H, Chen P, Wang D, Ren J, Zhang Y. Physical Exercise and Selective Autophagy: Benefit and Risk on Cardiovascular Health. Cells. 2019;8(11):1436. Published 2019 Nov 14 doi:10.3390/cells8111436

\section{Source of Support: Nil Conflict of Interest: None Declared}

How to cite this URL: Vaidya Anita Choudhary: A Review: A Concept Of Autophagy With Special Reference To Paachana Therapy. International Ayurvedic Medical Journal \{online\} 2021 \{cited September 2021\} Available from: http://www.iamj.in/posts/images/upload/2140_2143.pdf 